\title{
LAW ENFORCEMENT OF DESTRUCTIVE FISHING IN INDONESIAN SEAS
}

\author{
Ook Mufrohim \\ Diponegoro University Semarang \\ mufrohimook@gmail.com \\ Joko Setiyono \\ Diponegoro University Semarang \\ jokosetiyono1961@gmail.com
}

\begin{abstract}
Indonesia is a country consisting of many islands. This makes Indonesia rich in natural marine resources consisting of marine products such as fish and other marine animals. Catching fish by means of damage or (destructive fishing) using trawlers, fish bombs, fish anesthesia needs special attention in terms of law enforcement, to support the protection of marine ecosystems and enforcement of existing regulations. This study uses a qualitative method with a normative juridical approach. This research shows weaknesses in committing destructive fishing crimes. This is intended so that law enforcers can enforce according to the provisions of the statutory regulations that are willing, and seek additional personnel or carry out strategies so that they can carry out surveillance in the Indonesian sea from catching fish in destructive ways.
\end{abstract}

Keyword: Destructive Fishing, Fishery, Law Enforcement

\section{A. INTRODUCTION}

The Indonesian sea is the largest part that has the wealth contained in it for the use of the people's welfare, prioritizing as stipulated in the 1945 Constitution. Natural wealth that can be enjoyed by people who live on marine animals in the form of fish, squid, and so on. Many fishermen depend on fishing for their marine products. The sea that is owned by Indonesia has fish and the potential resources in it that need to be balanced with fish catchers who comply with applicable regulations so as not to damage the marine ecosystem and the sustainability of coral reefs in it. The Unitary State of the Republic of Indonesia (NKRI) has 13,466 islands which are registered and coordinated. The total area of Indonesian jurisdiction at sea is estimated to be 2.8 million $\mathrm{km} 2$ for the area of Indonesian archipelago waters, 0.3 million $\mathrm{km} 2$ of marine territorial waters and $2.7 \mathrm{~km} 2$ for the area of the Exclusive Economic Zone (EEZ). The government has the responsibility of protecting and maintaining the integrity of the sovereign territory and the jurisdiction of the state because territory is one of the conditions for the formation of a state in Article 1 of the Montevideo Convention of 1933 concerning the rights and obligations of 
the state. ${ }^{1}$ so most of the territories formed by the very wide and diverse seaside that has the potential of fish can be utilized for the future of the nation, as the spearhead of national development. ${ }^{2}$

In this regard, technological advances in this 4.0 technology generation will certainly also increase in the interests of individuals but will still take precedence over the public interest. To protect the sea from being targeted in illegal fishing, it is necessary to establish a rule of law to be a guideline for fish, it must be enforced by the government so that the sea so far the source of Indonesia's wealth of income can be protected, and how the law can help improve the presence of illegal and destructive fishing.

Illegal fishing occurs mostly in Indonesian marine waters, in the form of fishing using methods that can damage the ecosystem distructive fishing including fishing using fish bombs, using fish anesthesia, and using trawlers. Catching in this way can damage marine ecosystems, coral reefs, marine biota and the survival of marine animals, the biggest impact is the amount of productivity of marine products will decline and even the potential of Indonesia's abundant sea is threatened with extinction. Improving the legal function in order to create order from various threats that can damage and guarantee the sustainability of the marine ecosystem is very necessary to do. With so many ways of catching fish carried out by the community where it is a way that damages the marine ecosystem such as catching fish using bombs, anesthetists and trawlers with the aim to get a lot of fish and in a fast time so that many fishermen act to follow government regulations in the interests of which at this time, the law must play a role in enforcing violations and imposing sanctions on fishing offenders who violate the rules stipulated in Law No.31 of 2004 concerning fisheries. Various efforts were made to save the sea and its wealth from perpetrators of crime, both in the form of criminal penalties, to the sinking of ships against perpetrators. However, it is still common to find people who catch fish using methods that are not friendly to the sustainability of the marine ecosystem, so it is necessary to re-establish the legal function in protecting marine wealth and justice for fishing actors who use destructive methods. This research is a normative law research by means of a statutory approach. The normative juridical research method is to emphasize juridical norms and rules such as statutory regulations and other matters relating to how to examine library materials or secondary data materials .

The research source is to use data obtained by examining primary legal materials, namely statutory regulations and secondary legal materials in the form of doctrines from legal literature and scientific research, and associated with the enforcement of illegal fishing in Indonesia. For this reason, in this paper, the author will examine Law Enforcement Of Destructive Fishing In Indonesian Seas.

1 Adista, Febrika Ganang. Tinjauan Mengenai Konsep Maritime safety Belt Indonesian dalam Upaya Perlindungan Wilayah Negara Kesatuan Republik Indonesia. Belli Ac Pacis.1.1, 2015)Page.82

2 Rifai, Eddy \& Khaidi Anwar. Politik hukum Penanggulangan Tindak Pidana Perikanan. Media Hukum. 21.2, 2014. Page. 280 


\section{B. DISCUSSION}

\section{Regulation of Juridic Implementation of Criminal Distructive Fishing In Indonesia}

Law enforcement is an effort to create the values of certainty, justice and benefit in society. For this reason, law enforcement is a process in upholding the values of the law. Law enforcement itself cannot be separated from the existence of violations and crimes in society and there are rules in the law that are prohibited by the community. The law enforcement process will involve many things. That law enforcement is inseparable from the activity of resolving the values contained in the embodied values and the attitude of action as a series to create the final value translation, maintaining and maintaining peace of life.

Fishing in an irresponsible way also includes fishing in a destructive way. Catching fish in this way causes a lot of harm to the marine ecosystem and the marine resources contained therein. Destructive fishing can be done using bombing methods, or under anesthesia. Using materials that can damage coral reefs and kill other animals from small to large species that are affected by fishing using bombs or anesthesia Catching fish using a fish bomb is an act that is categorized as a criminal act. This is because one of the media can cause damage by releasing the tremendous energy or force that is generated from the explosion. The resulting explosion inflicted damage to the environment in which the bomb was detonated. The fish bomb itself is shaped like a container and contains explosives in it and can be adjusted to cause damage when detonated. ${ }^{3}$

According to Alimuddin \& $\mathrm{H}$. Supriadi, the fishery products captured by the State of Indon esia in 2007 were 4,924,430 tons. ${ }^{4}$ The high yield of fishing, resulting in fishermen or fishing companies in catching fish often occurs illegally. Illegal fishing in exploitation in the form of ikn bombs, anesthetists and trawlers and using destructive fishing

Destructive fishing is a criminal act that is contrary to Law No.31 of 2004 concerning Fisheries, Article 84 that "Every person who deliberately in the Indonesian Fish Cultivation Territory catches fish and / or cultivates fish using chemical, biological, Explosives, tools and / or methods, and / or buildings that can harm and / or endanger the conservation of fish resources and / or the environment as referred to in Article 8 paragraph (1), shall be punished with imprisonment of up to 6 (six) years and a maximum fine of Rp1,200,000,000.00 (one billion two hundred million rupiah)" and Article 85 of Law No.31 of 2004 concerning Fisheries which reads "Everyone who deliberately in the Indonesian Fish Cultivation Territory owns, controls, carries, and / or uses fishing gear

3 Marwan P \& Jimmy P. Kamus Hukum (dictionary of law Complete Edition). Reality Publisher. Surabaya. 2009. Page. 111

4 Supriyadi Amiluddin. Hukum Perikanan di Indonesia. Sinar Grafika. Jakarta. 2011. Page.22 
and / or fishing aid in fishing vessels that do not comply with the stipulated size, fishing gears that do not comply with the requirements, or standards stipulated for certain types of gears and / or fishing gears which are prohibited as referred to in Article 9, shall be punished with imprisonment of a maximum of 5 . five) years and a maximum fine of $R p$. $2,000,000,000.00$ (two billion rupiah) ".As a result of the behavior of the bomb, Fish Anesthetist can cause damage to marine animal life and slow marine conservation and violate marine protection, which includes the protection of marine animals and fisheries.

Marine biodiversity will also be threatened if Distructive fishing continues, Muhamad Erwin stated that polluted beaches, the occurrence of sediment is the result of logging in the upstream forest, fishing in destructive ways such as using poison and bombing, digging coral and coral reefs. also biodiversity in Indonesia will be threatened. ${ }^{5}$

Indonesian criminal law requires a firmness in tackling the crime of Destructive Fishing. This is proven by the capture of fish using methods that are not friendly to ecosystems and marine biota, as is the case with fishing using Fish Bombs carried out in fisheries areas that are included in East Flores Regency.

So with that law enforcement officers need to take repressive actions in accordance with applicable law, if there is a violation of the law. ${ }^{6}$

\section{a. Juridical Basis for Distructive Fishing Crimes}

Based on Article 84 of Law Number 31 year 2004 Concerning Fisheries, it states that: ${ }^{7}$

(1) "Anyone who deliberately in the Indonesian Fish Cultivation Territory is catching fish and / or breeding fish by using chemicals, biological materials, explosives, tools and / or methods, and / or structures that can harm and / or endanger the preservation of resources. fish and / or their environment as referred to in Article 8 paragraph (1), shall be punished with imprisonment for a maximum of 6 (six) years and a maximum fine of Rp1,200,000,000.00 (one billion two hundred million rupiah) "

The elements of fisheries criminal act according to Law Number 31 of 2004 concerning fisheries (Law No.31 of 2004) and the Amended Law Number 45 of 2009 concerning fisheries (Law No. 45 of 2009) are:

1) Each Person

2) Captain, Submariner

3) Fishing boat owner

4) Fish Breeders ${ }^{8}$

5 Muhammad Erwin. Hukum Lingkungan dalam sitem kebijakan pembangunan lingkungan hidup. Refika Aditama, Bandung. 2009. Page.156

6 Titik Triwulantutik. Pengantar Hukum Tata Usaha Negara Indonesia. Prestasi Pustaka. Jakarta. 2010. Page.282-283

7 Undang-Undang No 31 Tahun 2004 tentang Perikanan 
The community or in this case the company that intends to carry out fish catching funds or other marine resources, would like to use fishing equipment in accordance with the stipulated provisions and not violate them as stipulated in Article 9 of Law No. 45 of 2009 Regarding Amendments to Law No. 31 of 2004 Concerning Fisheries that is:

(1) "Every person is prohibited from owning, controlling, carrying and / or using fishing equipment that disturbs and can destroy fish resources in the fishery territory of the Republic of Indonesia. ". 9

In the event of a criminal offense at sea, an investigation is carried out as a process to find preliminary evidence, whether the event is actually a criminal act or not, in this case the authority to conduct an investigation as according to Law Number 45 of 2009 concerning Amendment to Law Number 31 of 2004 concerning Fisheries, that is:

Article 73:

(1) "Investigation of criminal acts in the field of establishment in the fisheries management area of the Republic of Indonesia is carried out by Civil Servant Fisheries Investigators, Indonesian Navy Investigators, and / or Republic of Indonesia National Police Investigators."

(2) "Apart from the Indonesian Navy investigators, the Fisheries Civil Servant Investigators have the authority to carry out investigations into fisheries crimes that have occurred at ZEEI. "

(3) "Investigations of criminal acts in the field of fisheries that occur at fishing ports, are prioritized to be carried out by Fishery Civil Servant Investigators."

(4) Investigations of criminal acts in the field of fisheries that occur at fishing ports, are prioritized to be carried out by Fishery Civil Servant Investigators."

(5) Investigators as intended in paragraph (1) can coordinate in the handling of investigations of criminal acts in the field of fisheries. "

(6) "To coordinate the handling of criminal investigations in the fisheries sector as referred to in paragraph (4), the Minister of $10 " 1$

These provisions are the basis in carrying out law enforcement against the criminal act of Illegal Fishing, which catches fish in a way that is Destructive Fishing. Perpetrators must

8 Aziz Syamsudin. Tindak Pidanan Khusus. Sinar Grafika . Jakarta. 2011. Page.38

9 Undang-Undang Nomor 45 Tahun 2009 Tentang Perubahan atas Undang-undang Nomor 31 Tahun 2004 Tentang Perikanan

10 Ibid. Page. 24 
get legal sanctions for the act of fishing by damaging and violating thec provisions of the legislation.

Law enforcement must be applied in order to create a deterrent effect on criminal offenders. Law enforcement itself is the most important thing to realize the objectives of the form of legal products or legal objectives, then it can be understood by law enforcement agencies with the aim of law enforcement being able to carry out good enforcement in life or enforcing criminal acts. According to Soerjono Soekanto, conceptually, the essence and meaning of law enforcement lies in the harmony of tilapia that is contained and embodies the attitude of acting in the implementation of the final value in order to create, preserve, and maintain the harmony of life relationships. ${ }^{11}$

The implementation of law enforcement requires the support of several things that affect effectiveness. "According to $S$. Soekanto, the matter is as follows: (1). Relating to the law itself; (2). Relating to law enforcement officials (APH); (3). facilities and facilities that support law enforcement; (4). Public; and (5) culture. (6) related to the influence of the effectiveness of law enforcement, if it is further examined the actual theory is part of the theory put forward by Lawrence $M$. Friedman regarding the legal system

In Hamid Chalid's quote, According to Lawrence M. Friedman, the legal system itself is divided into 3 things, namely: legal structure, (legal substance and legal culture. Law enforcement officers themselves as part of the legal structure consisting of civil servant investigators, marine police, prosecutors and courts are complete enough to enforce the law against crimes committed in maritime territories. However, they still have constraints in the form of a lack of human resources in carrying out tasks in the sea area because the Indonesian sea is so vast, it is felt that there are still many gaps for perpetrators of criminal acts to make illegal arrests due to a lack of guardians from law enforcement officers who have limited human resources

For that, Legal Substance as with the laws and regulations as Law No. 31 of 2004, Law No. 45 of 2009 concerning amendments to Law No. 31 of 2004 concerning fisheries, Law No. 32 of 2014 concerning Maritime Affairs It is sufficiently good to accommodate criminal offenses occurring in the territorial territories of the sea, and criminal offenses for illegal capture of marine products, and in destructive ways, should be sufficient in carrying out law enforcement so as to protect Indonesia's natural marine resources so that they can be used as well as possible. -baiknya and for the prosperity of the people of Indonesia.

Legal Culture itself, is expected to be a very central thing in the process of reforming criminal law, it is hoped that the

11 Soerjono Soekanto. Faktor Faktor yang mempengaruhi Penegakan hukum. Raja Grafindo. Jakarta. 2012. Page.5 
community will be aware of what they should do in fishing, and other marine products by using ways that are more friendly to marine ecosystems, the way in which allowed by the State, and does not damage the sustainability of other marine life. But it is unfortunate when the community's role in catching fish and marine products still eliminates all methods of using bombs, lure tigers and so on, this is very dangerous for marine ecosystems, damage to coral reefs, and danger to other communities who later when marine ecosystems damaged then, the results of the sea that will be less and less. The community still needs continuous socialization so that both the small fishing community and the fish company will leave the method and use a more humane method.

\section{b. Causes of the Distructive Fishing Criminal Measures}

Fishing activities using distructive fishing are motivated by economic and social factors. economic factors, fishing with lots and ways that are effective, efficient and easy to be able to meet basic needs without having to think there will be damage to the potential and resources of fish. The increasing need for fish in the market where this makes fishermen must be able to meet market needs so that they get daily income that is often uncertain, then the assembly and there are suppliers of destructive fishing gear such as fish bombs resulting in fishermen who choose practical ways but damage the environment because they feel unable to buy fishing equipment that is determined by laws and regulations.

While social factors are known that fishing for distructive fishing is fishing using bombs in Indonesia since ancestral heritage and continues today. So the habit of things has become a habit in catching fish using bombs, anesthetists and trawlers. It has become a culture alternating from generation to generation so that it becomes mental and personality in terms of fishing using methods that are instant and damage the marine ecosystem.

One of the causes of Distructive Fishing activities in Indonesian waters, namely: "lack of facilities and infrastructure to conduct surveillance, lack of operational funds to conduct patrols, lack of members of the marine police / Navy to conduct surveillance and patrols and the lack of Civil Servant Investigators, still lack of expertise possessed by Indonesian fishermen to be able to maximize the potential of fish in Indonesian sea waters in a good way, there is a need for raw materials for illegal fishing. The extent of the territory and the distance of the fisheries court with the locus delicti illegal fishing is also one of the factors causing the increase in illegal fishing by illegall ${ }^{12}$.

The following are the causes of illegal and destructive fishing or Distructive Fishing:

12 Yunitasari, Desi. Penegakan Hukum Di Wilayah Laut Indonesia Terhadap Kapal Asing Yang Melakukan Illegal Fishing Mengacu Pada Konvensi United Nations Convention On Law Of The Sea 1982. Jurnal Pendidikan Kewarganegaraan Undiksha 8.1 2020. Page. 63. 
1) There is a desire to get fish in large quantities and quickly

2) A lot of competition between fishermen and or fishing companies

3) Lack of guarding of the sea area, causing fishing to be carried out in destructive ways;

4) Expensive fishing equipment recommended and they cannot afford to buy;

5) It has become part of the heritage of ancestors, catching fish with bombs, anesthetists and trawlers.

\section{Obstacles in Action of Distructive Criminal Measures in Indonesia Area}

Criminal law enforcement is a part that determines the rule of law. In the process of conducting law enforcement, there is a very important role for investigators to conduct investigations, this becomes important because investigators are part of the mechanism in the process of the criminal justice system (SPP). Efforts to enforce fisheries in the region have become a vital process to support the sustainability of Indonesia's marine fisheries development so that they can be constrained and in accordance with the rules for the management and utilization of fisheries. so that later it will realize development in the field of fisheries that is better and more sustainable. Therefore, legal certainty is needed in conditions such as to be able to provide clarity as well as certainty to carry out enforcement of criminal acts carried out which include investigations, prosecutions, and examinations in court proceedings. $^{13}$

In carrying out criminal law enforcement in the form of destructive fishing crimes, often experience obstacles faced by the authorities. Among them:

a. Limited Police Personnel

In carrying out law enforcement, there are causes caused at sea and can not be resolved properly because when police will carry out law enforcement or patrol at sea is still limited by the number of existing members, given the vast area of Indonesian territorial waters and perceived existing members insufficient to conduct patrol or surveillance in the sea area.

b. Limited Infrastructure available

In carrying out law enforcement, there are obstacles faced in the form of a lack of supporting facilities that are owned by law enforcement officers, so that the lack of facilities and infrastructure in the form of a limited fleet of ships owned at each post becomes one of the factors of law enforcement at sea.

c. Limited Operational Costs

Operational costs become a very important part of conducting enforcement in the sea area, but the operational costs have not been

13 Lego, Indra Rusdian. Penegakan Hukum Tindak Pidana Perikanan Terhadap Ilegal Fishing Melalui Mekanisme Penenggelaman Kapal. Jurnal Akrab Juara 3.3. 2018. Page.115 
sufficient to be able to accommodate law enforcement activities so that this is still a part of obstacles in conducting law enforcement.

d. Natural Factors

Nature is also a part of the obstacles in enforcing, where Indonesian seas are still often found illegally fishing due to natural factors. Where it is necessary to know that fishing uses destructive methods due to the location of natural factors of the vast Indonesian waters. So many people commit crimes because catching fish using bombs, anesthesia and trawling tigers is very easy, after making arrests in this way the perpetrators can freely go far in other marine waters to eliminate traces so that it is difficult to be scouted by sea police

e. Efforts to Control

1) Preventive Action

With the many obstacles experienced in enforcing the law, it is felt necessary to prevent crime by means of preventive means, where preventive prevention is a way to prevent the occurrence of criminal acts of fishing by means of distructive ways. Preventive efforts can be in the form of counseling to fishermen related to procedures for catching fish properly in accordance with government regulations. it is hoped that routine counseling will be able to build awareness and care for the wealth or company in order to catch fish in a way that is not destructive in order to preserve the potential of Indonesia's marine wealth. The counseling is done routinely, and can be in the form of:

a) Catch Fish in a goof and non-destructive way

b) Fishing in accordance with the law;

c) The legal consequences if violating the fisheries law;

d) The impact caused when fishing using prohibited methods such as bombs, these tools are prohibited because they can inhibit fish populations, damage coral reefs, and damage existing marine ecosystems.

2) Repressive actions

This action is a legal action taken after the preventive action. Repressive action itself is understood as one of the social controls. namely that when there is a violation of the rule of law, it will be a control for law enforcement officers through repressive and sanctions that have been set in the applicable law. This is done with the aim of protecting the rights of the community and the marine environment. Thus it is in agreement with Sadjijono who states that the concept of legal protection is the function of the police, so to be able to improve that function the community must comply with applicable laws and maintain and obey orders. ${ }^{14}$

14 Sadjijono. Hukum Kepolisian POLRI dan Good Govement. Laksbang Mediatama. Surabaya. 2009. Page. 91 
According to Marhaeni Ria Siombo Relating to the rights of fishermen in the field of fisheries, that the fishermen who catch fish are a job to earn a living and can meet the necessities of life then in this context enter into the State's obligation to be able to protect the rights as the state of his country. ${ }^{15}$

On the other hand there is the right of the fishermen to be able to carry out fishing activities, but it is also mandatory to carry out ways to catch fish properly and maintain the sustainability of existing marine resources. If fishermen do not carry out the obligation to preserve marine resources, they must get sanctions in the form of criminal law or fines.

\section{3) Curative Action}

Tshis action is in the context of following up the awareness of crime so that they do not take action again. This action was carried out between repressive and preventive actions.

\section{CONCLUSION}

The conclusion taken by the authors from the above explanation is that the law enforcement process against the criminal act of distructive fishing is still weak and needs to be implemented if there is a criminal act of distructive fishing in Indonesian marine waters, so that the community will experience a deterrent period due to their actions of catching fish with destructive ways, so that people will realize that the sustainability of the marine ecosystem and marine natural resources will later be used and utilized and obtained by themselves and / or by their children and grandchildren. And in enforcing the criminal act of destructive fishing in Indonesian waters, law enforcement officials including Civil Service Investigators, Police Investigators, Navy TNL, experience difficulties due to the vastness of Indonesia's marine waters and are not balanced with sufficient equipment and resources, so they often miss information and time when there are fishermen or criminal offenders who are fishing in a destructive way.

\section{BIBLIOGRAPHY}

\section{Book}

Aziz Syamsudin. 2011. Tindak Pidana Khusus. Sinar Grafika. Jakarta;

Erwin M. 2009. Hukum Lingkungan (Dalam Sistem Kebijakan Pembangunan Lingkungan Hidup). Refika Aditama. Bandung;

Chalid. Hamid. 2009. Menuju Kejaksaan Progresif (Studi tentang Penyelidikan, Penyidikan dan Penuntutan Tindak Pidana Korupsi). Jakarta:

15 Marheini ria Siombo, Hukum Perikanan Nasional dan Internasional. PT. Gramedia Pustaka Utama. Jakarta. 2010. Page.28-29 
Jimmy P. \& Marwan M. 2009. Kamus Hukum (Dictionary of Law Complete Edition). Surabaya : Reality Publisher

Titik Triwulan T. 2010. Pengantar hukum tata Usaha Negara Indonesia. Prestasi Pustaka. Jakarta;

Sadjijono. 2009. Hukum kepolisian POLRI dan Good Governance. Laksbang Mediatama. Surabaya;

Soerjono Soekanto. 2012. Faktor-faktor yang mempengaruhi penegakan Hukum. Raja Grafindo Persada. Jakarta;

Supriyadi . A. 2011. Hukum Perikanan di Indoesia. Sinar grafika, Jakarta;

\section{Journal}

Adista, Febrika Ganang. Tinjauan Mengenai Konsep Maritime safety Belt Indonesian dalam Upaya Perlindungan Wilayah Negara Kesatuan Republik Indonesia. Belli Ac Pacis.1.1. 2015;

Lego,Indra Rusdian. Penegakan Hukum Tindak Pidana Perikanan terhadap Illergal fishing melalui mekanisme penengelaman kapal. Jurnal Akbar Juara. 2018;

Fernandes, Inggit. Tinjauan Yuridis Illegal Fishig di Perairan Indonesia Berdasarkan Undang-Undang Perikanan. Jurnal Hukum Respublica. Vol 17. No 1. 2017;

Hartanto. Maritime Transpoertation in Indonesia Policy. Jurnal Pembaharuan Hukum. Vol. VI. No 2. 2019;

Rifai, Eddy \& Khaidi Anwar. Politik hukum Penanggulangan Tindak Pidana Perikanan. Media Hukum. 21.2. 2014;

Risnain, Muh. Rekonsepsi Model Pencegahan dan Pemberantasan Illegal Fishing di Indonesia. Padjajaran Jurnal Ilmu Hukum. Vol 4 No 2. 2017; 